\title{
Development of Thematic Educational Game Eduklok Chemistry Based on Indonesian Local Wisdom
}

\author{
Iis Nilam Cahya ${ }^{1, *}$, Ratih Dwi Astuti ${ }^{2}$, Septiana Hanif ${ }^{3}$ \\ ${ }^{1}$ Physics Education; ${ }^{2}$ Chemistry; ${ }^{3}$ Chemistry Education, UIN Sunan Kalijaga \\ Email*: iisnilam01@gmail.com
}

\begin{abstract}
The purpose of this research is to develop a media in the form of educational games that contain local wisdom content, culture, culinary, and health, which are packaged in a snake and ladder game. In addition, this study also aims to test the quality and analyze user perceptions of the "Eduklok Chemistry" game product that has been developed. The method used in this research is to adapt the ADDIE model which includes the stages of analysis, design, and development. The quality of the developed product is tested by the expert judgment method using an expert assessment instrument to get a quality score. The study of users' perceptions of the product is carried out by the method of analyzing user responses to assess user perceptions in the form of response data. Quality test results by material experts that the product developed is included in the category of Very Good (SB) with a percentage of ideals of $100 \%$. The results of quality tests by media experts on products developed are included in the category of Good (B) with a percentage of ideals of 76.92\%. Meanwhile, the results of user perception studies show that most users respond Very Good (SB).
\end{abstract}

Keywords: eduklok chemistry, local wisdom, educational game.

Abbreviations: ADDIE (Analysis Design Development Implementation and Evaluation).

\section{INTRODUCTION}

According to Endang Saefudin Ansori in Rusuli \& M. Daud (2015: 13) Knowledge is a human understanding effort that is compiled about the reality, structure, parts, and laws of the things being investigated (natural, human, and religious) which can be reached by the power of thought assisted by sensing whose truth can be empirically tested, researched, and experimented. In the past, the spread of knowledge was still very exclusive only to priests and aristocrats, palace or kingdom, and educated groups so that the general public's accessibility to science was very limited because it did not reach the wider community.

According to the total number of cultural inheritance criteria for local wisdom in 2015 conducted by the ministry of education and culture, that Indonesia has a total of 384 local wisdom from 34 provinces in Indonesia (Kemendikbud, 2016). The importance of inheriting and disseminating Indonesian local wisdom culture has been regulated in the 1945 Constitution No. 5 of 2017 concerning the promotion of culture, that regional cultural diversity is a wealth and national identity that is very much needed to advance Indonesia's national culture amidst the dynamics of world development so that efforts must be made in passing down local wisdom. Knowledge in the form of local wisdom, art, culture, culinary skills, and medical traditions need to be passed on and disseminated to the current generation (millennial) and future generations, one of them by making digital records. Media that can be used are smart phones.

According to Ivan C. Sibero in (Harsono, 2014) Games are the most widely used and enjoyed applications by electronic media users because playing games does not recognize the age and status of the community. Educational game is an application on a smart phone which is one of the fun media that is able to save and disseminate the legacy of local wisdom in arts, culture, medical traditions, and culinary skills as a form of knowledge to present and future generations.

In this research, a media sharing knowledge will be developed in the form of a thematic educational game for local wisdom that contains local wisdom content, culture, culinary and health in the perspective of chemistry. Media sharing knowledge (knowledge sharing) in the form of educational games is expected to save and disseminate the legacy of chemical knowledge in local wisdom, culture, health, and culinary. The media developed is the thematic educational game "Eduklok Chemistry" based on Indonesian local wisdom that can be operated on an android smart phone that is packaged in a snake and ladder game. The thematic educational game that was developed contains three features namely game features, chemistry education features and local wisdom features.

\section{METHOD}

This study uses the ADDIE model which includes stages of analysis, design, development, implementation, and 
evaluation. However, this research phase only reached the development stage. The first stage, an analysis of the problems that exist in the community so that a solution is needed in the form of developing various media knowledge. At this stage the questionnaire was distributed to the public. The second stage, the design is done first collecting reference material, compiling the material, validating the material, selecting the media, and making the initial design. The third stage, carried out the development stage.

Quality tests are carried out by material experts and media experts to determine the quality of the results of the development of the thematic education game "Eduklok Chemistry" based on Indonesian local wisdom. The type of data obtained in the form of qualitative data with the value of the category "Yes" or "No", and quantitative data obtained in the form of a score for the category of "Yes" was given a score of 1 while for the category of "No" was given a score of 0 .

The assessment instrument used for quality testing uses a quality assessment sheet, for media experts as well as material experts, namely using an expert assessment instrument using the Gutman scale. (Sukardi, 2010)

Analysis of user responses is carried out by the public using the method of analysis of responses to products. The type of data obtained in this study is the user's perception of the product developed in the form of qualitative data and quantitative data. Qualitative data are in the form of SS (Highly Agree), S (Agree), KS (Disagree), TS (Disagree), STS (Strongly Disagree) values. While quantitative assessment scores are $\mathrm{SS}=5$, $\mathrm{S}=4, \mathrm{KS}=3, \mathrm{TS}=2, \mathrm{STS}=1$.

\section{RESULTS AND DISCUSSION}

\section{Results}

Quality test of the "Eduklok Chemistry" thematic educational game by media experts

Table 1. Data on expert quality assessment of all aspects of the material.

\begin{tabular}{|c|c|c|c|c|c|c|}
\hline No & Aspect & Indicator & $\begin{array}{l}\text { Score by } \\
\text { category }\end{array}$ & $\begin{array}{l}\text { Max score } \\
\text { by category }\end{array}$ & $\begin{array}{l}\text { Percentage } \\
\text { of ideals }(\%)\end{array}$ & Category \\
\hline \multirow{3}{*}{1} & \multirow{3}{*}{ Button } & All buttons function properly & 0 & 1 & \multirow{3}{*}{$66,67 \%$} & \multirow{3}{*}{ Good } \\
\hline & & $\begin{array}{l}\text { Button gives menu offer that matches the } \\
\text { selected menu }\end{array}$ & 1 & 1 & & \\
\hline & & Button makes it easy for users to run the game & 1 & 1 & & \\
\hline \multirow{3}{*}{2} & \multirow{3}{*}{ Text } & Text can be read Clearly & 1 & 1 & \multirow{3}{*}{100} & \multirow{3}{*}{$\begin{array}{l}\text { Very } \\
\text { Good }\end{array}$} \\
\hline & & Font size is Consistent & 1 & 1 & & \\
\hline & & Match between type and size alphabet & 1 & 1 & & \\
\hline \multirow{6}{*}{3} & \multirow{6}{*}{$\begin{array}{l}\text { Audio and } \\
\text { visual display }\end{array}$} & Sound effect Selection & 1 & 1 & \multirow{6}{*}{66,67} & \multirow{6}{*}{ Good } \\
\hline & & Music selection & 1 & 1 & & \\
\hline & & $\begin{array}{l}\text { Color match, drawings and layout design in the } \\
\text { game }\end{array}$ & 0 & 1 & & \\
\hline & & $\begin{array}{l}\text { Layout clarity Interactive (icon navigation) in the } \\
\text { game }\end{array}$ & 1 & 1 & & \\
\hline & & Suitability of background selection & 0 & 1 & & \\
\hline & & Simple and clear design & 1 & 1 & & \\
\hline \multirow[t]{2}{*}{4} & $\begin{array}{l}\text { Product } \\
\text { Characteristics }\end{array}$ & $\begin{array}{l}\text { Game used as a media for sharing chemical } \\
\text { knowledge in informal local wisdom }\end{array}$ & 1 & 1 & 100 & $\begin{array}{l}\text { Very } \\
\text { Good }\end{array}$ \\
\hline & & Total ideals & 10 & 13 & $76,92 \%$ & Good \\
\hline
\end{tabular}

Quality test of the "Eduklok Chemistry" thematic educational game by product users

Table 2. Data on overall user response aspects

\begin{tabular}{clllll}
\hline No & Assessment Aspects & Score by category & Max score by category & Percentage of ideals & Category \\
\hline 1 & Material & 779 & 900 & 86,55 & Very Good \\
2 & Linguistics and TExt & 184 & 225 & 81,73 & Good \\
3 & Audio and visual display & 369 & 450 & 81,76 & Good \\
4 & Users simplicity & 194 & 225 & 86,20 & Very Good \\
5 & Product characteristics & 67 & 75 & 98,20 & Very Good \\
\hline & Total ideals & 1598 & 1875 & 82,24 & Very Good \\
\hline
\end{tabular}




\section{DISCUSSION}

The development of the thematic educational game "Eduklok Chemistry" based on Indonesian local wisdom was developed by adapting the ADDIE development model which consisted of the Analysis, Design, Development stage. Researchers limit their research to uploading games on the Google Play Store.

This educational game contains information on chemical knowledge penetrated in Indonesian local wisdom with local wisdom content, local wisdom, cultural arts and culinary local wisdom. Chemical knowledge contained in the game consists of 27 local wisdoms consisting of 11 local cultural arts wisdom, 9 culinary local wisdom and 7 local health wisdom. The existing chemical content is science, art and engineering.

The quality of educational games developed is determined based on the results of the validity and expert judgment. Validity test is the validation of chemical materials. Quality tests are carried out by expert judgments namely material experts and media experts using the Guttman Scale instrument which is obtained by the product quality score. Based on the assessment of material experts obtained the percentage of product quality that is Very Good (SB) with the acquisition of an average score $(\mathrm{X}) 13$ in the range of categories $10.5<\mathrm{X}$. Percentage of ideals obtained by $100 \%$. The assessment based on media experts obtained the percentage of ideals that is $76.92 \%$. Quality based on media experts obtained Good (B) quality based on the average value (X) obtained which is 10 in the range of quality categories $7.8<\mathrm{X} \leq 10.4$. Meanwhile, the results of user response analysis obtained user perception data that reflect satisfaction with the thematic educational game product "Eduklok Chemistry" based on the perception categorization analysis technique that is Very Good (SB) based on perceived value data (X) 106.53 are in the range of the category $105<\mathrm{X}$.

\section{CONCLUSIONS}

Based on the assessment that has been done in a series of studies that the game products developed have a minimum quality value of Good $(\mathbf{B})$ and a maximum of Very Good (SB), so that the game can be used as a media for sharing knowledge of local wisdom that contains local wisdom content of culture, health, and culinary in the perspective of chemistry intended for the wider community.

\section{ACKNOWLEDGEMENTS}

First we thank sister Septiana Hanif, S.Pd. who has allowed his research to be included in the third International Conference on Science and Engineering. Secondly, we thank the Faculty of Science and Technology for organizing this extraordinary event so that it can broaden our horizons. And the last thanks to our parents who always provide support both in prayer and financially.

\section{REFERENCES}

Harsono, M,. 2014. Pengaruh Bermain Game terhadap Perkembangan Remaja. Surya University: Serpong

Kemendikbud. 2016. Permendikbud Nomor 22 Tahun 2016 Tentang Standar Proses Pendidikan Dan Menengah. Jakarta: Kemendikbud

Rusuli, Izzatur., Zakiul, Fuady, M., Daud. 2015. Ilmu Pengetahuan dari John Locke ke Al-Attas. Jurnal Pencerahan Volume 9, Nomor 1.

Sukardi. 2010. Metodologi Penelitian Pendidikan. Jakarta: PT. Bumi Aksara 
THIS PAGE INTENTIONALLY LEFT BLANK 